\title{
Adoption of varietal and accompanying groundnut technologies in Sokoto and Kebbi States of Northwestern Nigeria
}

\author{
Michael B. Vabi ${ }^{1 \star}$, Hakeem A. Ajeigbe, Abba Aliyu Kasim, Sadiq Abubakar Sadiq ${ }^{2}$ and Lawal \\ Bala $^{1}$
}

${ }^{1}$ International Crops Research Institute for the Semi-Arid Tropics (ICRISAT), Nigeria.

${ }^{2}$ Kano State College of Arts, Science and Remedial Studies (CAS), Nigeria.

Accepted 12 April, 2019

\begin{abstract}
The most recent improved groundnut varieties with farmers in Nigeria are SAMNUT 23, SAMNUT 24, SAMNUT 25 and SAMNUT 26. Amongst other things, this paper summarises outcomes of an adoption survey of these varieties in Sokoto and Kebbi States of North-western Nigeria. A total of 110 respondents were selected from administrative units where a donor funded project is being executed (coded herein as PLGA) and 110 from administrative units where project actions are absent (coded herein as NPLGA). The survey reveals that improved groundnut varieties are being grown amidst several other varieties designated as local. While SAMNUT 24 is being grown by $39 \%$ of respondents in PLGA and $19 \%$ of those in NPLGA, Kampala (a local groundnut variety) is being planted by 35 and $40 \%$ of respondents in PLGA and NPLGA, respectively. Farming experience, level of education and household size were found to influence household decisions to adopt groundnut varietal technologies and accompanying crop management practices at 1, 5 and 10\% levels of significance. Gross Profit Margins in PLGA and NPLGA were 66,854 Naira (or \$219) and 23,744 Naira (or $\$ 78$ ), respectively, indicating that smallholder farmers could make nearly $64 \%$ additional cash incomes by adopting improved groundnut technologies.
\end{abstract}

Keywords: Adoption, groundnut technologies, Northwestern Nigeria.

*Corresponding author. E-mail: M.vabi@cgiar.org, michaelboboh@gmail.com. Tel: +234 8135636417, 2347018860163.

\section{INTRODUCTION}

\section{Background and objective pursued}

Groundnut (Arachis hypogaea L.) is one of the most important oil seed crops in the world. The FAO (2017) estimates that production of the crop stands at about 47 million metric tons cultivated on a total of 28 million hectares worldwide, with an average productivity of 1.6 tons/ha. Developing countries constitute $97 \%$ of the global area cultivated. Groundnut production is concentrated in Asia and Africa, where it is mostly grown under rain-fed conditions with limited external inputs (Ibrahim et al., 2012). Nigeria is the third world producer of the crop, after China and India. Depending on the variety, the oil content of the crop varies between 48 and $50 \%$, and protein content is estimated at between 26 and
$28 \%$ and between 11 and 27\% micro-nutrients (carbohydrate, minerals and vitamins). The crop is commonly consumed during harvesting, roasted/boiled and processed into oil by small-scale farmers and city dwelling women for domestic use and/or cash income generation. Like other legumes, groundnut is known to be a nitrogen accumulator - an attribute which makes it feasible for resource limited farmers to save expenses on organic fertilizers. According to Simtowe et al. (2008), its haulms and cake are rich in digestible crude protein and used as feed for ruminant livestock in the dry season in many countries of West and Central Africa (WCA).

Smallholder farmers in savannah agro-ecological regions of WCA are very much aware of the benefits of cultivating groundnut. Broadly, both local and improved 
varieties are planted in association with many other crops notably cereals. In Nigeria, the crop is produced in all the agro-ecological zones of the country, though cultivation is predominant in nineteen (19) States located within the Sahel, Sudan and Guinea agro-ecological zones. These States are: Federal Capital Territory (Federal Capital Territory/FCT-Abuja), Kano, Katsina, Kaduna, Jigawa, Sokoto, Zamfara, Kebbi, Adamawa, Bauchi, Yobe, Taraba, Borno, Benue, Plateau, Nasarawa, Kogi, Niger and Kwara (NAERLS, 2017).

A total of twenty-nine (29) varietal technologies have been registered and released for commercial use in Nigeria since 1990 (NACGRB, 2014). The scaling out of these improved varieties, together with accompanying crop management practices, have been the subject of the support of the United States Agency for International Development (USAID) to the International Crops Research Institute for the Semi-Arid Tropics (ICRISAT). In Nigeria, this project entitled Increasing Groundnut Productivity of Smallholder Farmers in Ghana, Mali and Nigeria is being implemented in partnership with twelve (12) partners with a focus on three improved groundnut varieties SAMNUT 24, SAMNUT 25 and SAMNUT 26. Upon registration and release, the key features of these varietal technologies are: high grain yields- estimated at 2-2.5 tons/ha instead of less than 1 ton/ha; high haulm yields - estimated at between 2.5-3tons/ha; early maturity - between 80-95 days, making it possible for them to escape end of season droughts compared to other varieties which generally mature at about 120 days; high oil contents - at least $45 \%$ oil when processed, moderate resistance to popular groundnut diseases notably early and late leaf spot diseases and rosette virus, small to medium pods and tan in colour making them fulfil both consumer and market preferences (Echekwu et al., 2012). Unlike many of the popular groundnut varieties, farmers describe these improved varieties as Atsaye (or erect).

This study was initiated to determine the adoption of the varietal technologies and accompanying crop management being scaled out by ICRISAT and national partners in two (2) out of five (5) States in North-western Nigeria. Project implementation started in January 2015 and the technologies being scaled out relate to varietal technologies, accompanying crop and aflatoxin management practices. All scaling out efforts were complemented by systematic capacity building interventions targeting groundnut value chain actors in the States.

\section{RESEARCH METHOLOGY}

\section{Sampling and sample selection}

A combination of purposive and multi-stage sampling procedures was used for the selection of respondents. The first stage of the sampling procedure was a straight forward decision to extend this survey to Sokoto and Kebbi after an enlightening survey in Kano,
Katsina and Jigawa as reported by Vabi et al. (2019). The second stage of the sampling procedure coincided with the confirmation of the eleven (11) Local Government Areas (LGAs) where the USAID funded project is being implemented (PLGAs) and a corresponding number were selected from LGAs where the project is not being implemented (NPLGA) resulting in a total of twenty-two (22) LGAs. The third stage in the sampling procedure consisted of a random selection of groundnut producing households with 110 from the PLGAs and NPLGAs. Giving a total of two hundred and twenty households (Table 1). Interviews were then conducted with representatives of households based on their availability and willingness to participate in the exercise. Representatives of selected households not available and/or not willing to participate in the interviews were replaced in consultation with ADP extension agents of each LGA and community leaders.

\section{Data collection and processing}

After prior hands-on survey briefing in each State, data were collected using a structured questionnaire by extension agents of the Sokoto and Kebbi ADPs. The data collected included: sex, farming experience, household size, level of formal education, different groundnut varieties being planted (local and improved), the use of accompanying crop management practices (including preand post-harvest management of aflatoxin), cash and non-cash incomes, constraints limiting the use of each of the recommended technologies. Data were collected between March and April 2018 with a focus on activities of the 2017 cropping season. Consistency checks on responses provided were carried out at the end of each day by State-based survey supervisors on all the filled out questionnaires. Data entry was carried out using SPSS - Statistical Package for the Social Sciences version 22. Frequency counts were used to summarize the data collected.

The Gross Profit Margin (GPM) and Return on investment (Rol) were used to establish the profitability of groundnut production (Edwards, 2016). The GPM was estimated using $=\sum p_{i} q_{1}-\sum r_{j} x_{j} ; p i$ where pi and qi represent the price and quantity of groundnut outputs, respectively, and $\mathrm{rj}$ and $\mathrm{xj}$ represent unit cost and quantity of the inputs used, respectively. Rol was determined by simply dividing the value of the GPM by total operational costs.

Modeling relationships between decisions to adopt or not to adopt agricultural technologies, usually requires the use of qualitative response models. Commonly used models are the binary probit model (which assumes an underlying normal distribution) and logit models (which take alogarithmic distribution functions). The logit model was used in this study to determine the drivers of farmers' decisions to adopt the improved groundnut varieties technologies considering that the model is simpler to interpret; it is also commonly used in adoption studies ( $\mathrm{Ng}$ 'ombe et al., 2014).

The binary logit model used for this study is presented as follows:

$$
\begin{aligned}
& A=\beta_{0}+\beta_{1} X_{1}+\beta_{2} X_{2}+\beta_{3} X_{3}+\beta_{4} X_{4}+\beta_{5} X_{5}+\beta_{6} X_{6}+u \\
& \text { Where: } \\
& A=\text { Adoption of recommended technologies (Adopted =1 or } \\
& \text { Rejected =0) } \\
& \beta_{0}=\text { intercept } \\
& \beta_{1} \text { to } \beta_{n}=\text { coefficients of } X_{1} \text { to } X_{n} \\
& u=\text { error term } \\
& X_{1} \text { to } X_{n}=\text { each of the factors considered to drive adoption decisions }
\end{aligned}
$$

\section{Background information about Sokoto and Kebbi States}

Both Sokoto and Kebbi States lie to the far extreme northwest of Nigeria (Figure 1); with both States sharing land borders with the 
Table 1. Summary of sample sizes in the three states retained for the study.

\begin{tabular}{llclc}
\hline State & PLGA & Number of households & NPLGA & Number of households \\
\hline \multirow{5}{*}{ Kebbi State } & Argungu & 10 & Arewa & 10 \\
& Aleiro & 10 & Bagudo & 10 \\
& Birinin Kebbi & 10 & Jega & 10 \\
& Dandi & 10 & Koko Besse & 10 \\
& Danko Wasagu & 10 & Sakaba & 10 \\
Sub-total & Maiyama & 10 & Yauri & 10 \\
& & 60 & & 60 \\
& & & & \\
\multirow{5}{*}{ Sokoto State } & 10 & Yabo & 10 \\
& Bodinga & 10 & Rabah & 10 \\
& Sange Shanari & 10 & Sabon Birni & 10 \\
Sub-total & Tambuwal & 10 & Tureta & 10 \\
Totals & Tangaza & 10 & Wurno & 10 \\
\hline
\end{tabular}

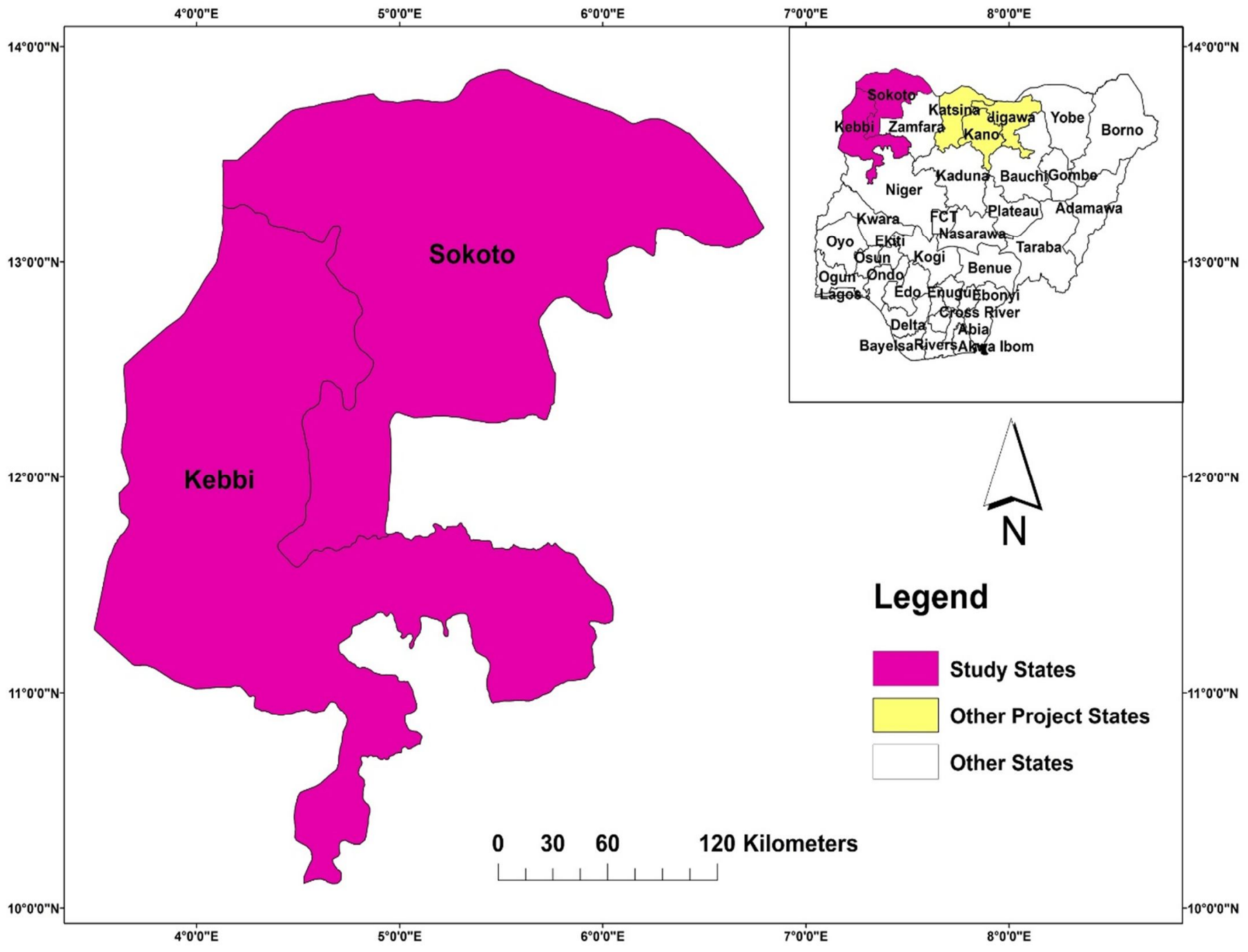

Figure 1. Map of the Federal Republic of Nigeria Showing Study States. Source: USAID Groundnut Upscaling M\&E. 
Republic of Niger hence providing vast opportunities for crossborder formal and informal exchanges. While Sokoto State has twenty-three (23) Local Government Areas (LGAs), Kebbi State twenty-one (21) LGAs. Both States have Agricultural and Rural Development Authorities, generally called ADP organized into Extension Zones (Dodo, 1996).

Using projections of 2006 National Population Census, the population of Sokoto State is estimated at 4,998,100 while that of Kebbi State is estimated at 4,917,327 (State-based Population Census Reports, 2006 and subsequent projections). With an annual national population growth rate of $3.3 \%$ and recurrent manipulations for different purposes, these figures have been changing and usually differ by source. The population primarily comprises the Hausa, Fulani and other ethnic/tribal groups. Christianity is also practiced in both States to a limited extent. Apart from Hausa and Fulani, other ethnic/tribal groups are also found in the two States. The main medium of communication is Hausa and Fulfulde.

Over eighty percent $(80 \%)$ of the population of both States are engaged in agriculture. The main crops produced are millet, sorghum (guinea corn), maize, rice, potatoes, cassava, groundnuts and common beans, these crops are grown for both subsistence and for sale. All categories of livestock - cattle, sheep, goats, chickens, camels and donkeys; cattle, camels and donkeys are frequently used for transportation and traction. Households resident along the Rivers Sokoto, Niger, Rima, dams and lakes also do fishing, and cultivate vegetables in the dry season.

Broadly, both States have dominant features of the Sudan and Savanah agro-ecological zones identified as appropriate for the improved groundnut varieties being promoted by the USAID project (Ajeigbe et al., 2015). The dry season starts from October, and lasts up to April and could extend to May or June in the southern parts of the States. The wet season generally begins in April-May and might extend to September-October. Mean annual rainfall ranges between 500 and $1,300 \mathrm{~mm}$. Annual average temperatures is $28.3^{\circ} \mathrm{C}$, with Sokoto being one of the hottest cities in the world, though maximum daytime temperatures stay around $40^{\circ} \mathrm{C}$ most of the year. The warmest months are February to April, where daytime temperatures can exceed $45^{\circ} \mathrm{C}$. In Kebbi State, mean annual temperature can be as high as $26^{\circ} \mathrm{C}$. However, between December and February, mean annual temperatures can go down to about $21^{\circ} \mathrm{C}$ and up to $40^{\circ} \mathrm{C}$ during the months of April to June. The highest recorded temperature in Sokoto has been $47.2^{\circ} \mathrm{C}$, which is also the highest recorded temperature in Nigeria.

A key motive for including both States into the USAID funded project was that they fall within the Feed the Future Zone of Influence (FtFZI). A total of 11 Local Government Areas (LGAs) were selected from both States with six (6) from Kebbi (out of a total of 27 LGAs) and five from Sokoto (out of a total of 23 LGAs).

\section{RESULTS AND DISCUSSION}

\section{Profile of households interviewed}

The socio-demographic profiles of representatives of the households interviewed in PLGAs and NPLGAs are summarised in Table 2. Most of those interviewed were men with $78 \%$ in PLGA and $92 \%$ in NPLGA, generally between 36 and 50 years of age. In both PLGA and NPLGA, household sizes vary between 2 and 49 with a mean of 14 persons. Mean farm size is about 2 hectares in both PLGA and NPLGA. Some have attempted formal education (28\%) and have even gone above primary education in NPLGA (24\%) compared to PLGA where some are better apt in Quranic education in PLGA. Many more $(88 \%)$ are members of farming groups in PLGAs than NPLGA $(63 \%)$ and reported having inherited their farm-fields (63\% PLGA and $66 \%$ in NPLGA). Mean farming experience of 23 years in PLGA and 28 years in NPLGA. Farm sizes emerged to be similar in both PLGA and NPLGA; mean of five (5) hectares with minimum and maximum of about one (1) hectare and fourteen (14) hectares, respectively. Similarly, mean land sizes devoted to groundnut production were about 2 hectares, though differences in maximum and minimum emerged in both PLGA and NPLGA. Farmers in PLGA estimated the values of their groundnut farms during the 2017 cropping season at 120,000 Naira (393 USD) in NPLGA as against 115,000 Naira (377USD) in PLGA; these were translated into mean values of $2,226,730$ (7,300 USD) for NPLGA and 2,093,650 Naira (686 USD) in PLGA.

The socio-demographic profile of respondents of this survey suggests that groundnut production in Sokoto and Kebbi States is dominated by men aged over 50 years, with thirty years working as farmers. Respondents have large household sizes and do not belong to farming groups. Farm-field devoted to groundnut production are less than two hectares, a majority of which are inherited. Adoption studies have often explained technology acceptance or rejection to socio-demographic profiles of end-users. Representative adoption studies include those of Mwangi and Kariuki (2015), Dhraief et al. (2018), Muhammad (2015), Mbavai et al. (2015), Bello et al. (2011), James (2014), Adzawla et al. (2016), Idoko and Sabo (2014), Melesse (2015), Njeuka et al. (2013), Lavison (2013), Thuo et al. (2014), Ndjeuga et al. (2011), Ndjeuga et al. (2012), Kassie et al. (2010), Kariyasa and Dewi (2011), Akudugu et al. (2012), Chianu and Tsujii (2004), Doss 2013 and Mauceri et al. (2005)

With respect to access to extension service delivery and support with improved groundnut varieties (Table 3), majority of respondents (82\%) in NPLGA report having monthly extension service support from ADP extension agents while $79 \%$ of those in PLGAs reported having extension service support from ADP extension agents though the periodicity of this extension service support was higher in PLGA (74\%) than in NPLGA (67\%). The key source credit (finances) for farm operations was from owned savings for respondents in both PLGA (62\%) and NPLGA (61\%). Though Foundation Seeds were given out either to farmer groups as in-kind loans by the USAID funded project; this was not perceived as credit by respondents in both PLGA and NPLGA in the two States. The equivalents of Foundation Seeds given out to community-based seed producers were recovered after harvest, drying and bagging.

The extension service is the key driving factor behind technology deployment and adoption. Access to regular and credible extension services could neutralise the negative effect of lack of formal education of farmers which could hinders technology adoption Agriculture extension is popular methods of introducing agricultural technologies to end users. Mwangi and Kariuki (2015), 
Table 2. Socio-demographic profile of respondents.

\begin{tabular}{|c|c|c|c|c|c|c|}
\hline \multirow{2}{*}{ Variable } & \multicolumn{2}{|c|}{ Kebbi State } & \multicolumn{2}{|c|}{ Sokoto State } & \multirow{2}{*}{$\begin{array}{l}\text { Pooled } \\
\text { PLGA }\end{array}$} & \multirow{2}{*}{$\begin{array}{l}\text { Results } \\
\text { NPLGA }\end{array}$} \\
\hline & PLGA & NPLGA & PLGA & NPLGA & & \\
\hline \multicolumn{7}{|l|}{ Sex } \\
\hline Female & $10(17)$ & $4(7)$ & $14(28)$ & $5(10)$ & $24(22)$ & $9(8)$ \\
\hline Male & $50(83)$ & $56(93)$ & $36(72)$ & $45(90)$ & $86(78)$ & $101(92)$ \\
\hline \multicolumn{7}{|l|}{ Age } \\
\hline $20-35$ & $2(3)$ & $4(7)$ & -- & 2(4) & $4(4)$ & $6(6)$ \\
\hline $36-50$ & $39(65)$ & $35(58)$ & $24(48)$ & $20(40)$ & $59(54)$ & $55(50)$ \\
\hline $51-65$ & $17(28)$ & 19(32) & $25(50)$ & $24(48)$ & $41(37)$ & $43(39)$ \\
\hline 66 and above & $2(3)$ & $2(3)$ & $1(2)$ & $4(8)$ & $6(6)$ & $6(6)$ \\
\hline \multicolumn{7}{|l|}{ Household size } \\
\hline Minimum & 2 & 2 & 3 & 2 & 3 & 2 \\
\hline Maximum & 30 & 59 & 30 & 39 & 30 & 49 \\
\hline Mean & 12 & 13 & 13 & 16 & 12 & 14 \\
\hline \multicolumn{7}{|l|}{ Education } \\
\hline Attempted formal education & $3(5)$ & $30(50)$ & 2(4) & $1(2)$ & $5(5)$ & $31(28)$ \\
\hline Above primary education & $13(22)$ & $12(20)$ & $9(18)$ & $14(28)$ & $22(20)$ & $26(24)$ \\
\hline Functional/Tertiary & $15(25)$ & $5(8.3)$ & $13(26)$ & $8(16)$ & $28(26)$ & $13(12)$ \\
\hline \multicolumn{7}{|l|}{ Member of a farming groups } \\
\hline Member & $50(83)$ & $34(43)$ & $47(94)$ & $7(14)$ & $97(88)$ & $41(37)$ \\
\hline Not a member & $10(17)$ & $26(57)$ & $3(6)$ & $43(86)$ & $13(12)$ & $69(63)$ \\
\hline \multicolumn{7}{|l|}{ Land ownership } \\
\hline Inherited & $37(62)$ & $35(58)$ & $32(64)$ & $38(76)$ & $69(63)$ & $73(66)$ \\
\hline Purchased & $12(20)$ & $10(17)$ & $9(18)$ & $10(20)$ & $21(19)$ & $20(18)$ \\
\hline Rented & $2(3)$ & $1(2)$ & $4(8)$ & -- & $6(6)$ & $1(1)$ \\
\hline Communal & -- & -- & 1(2) & -- & $1(1)$ & $0(0)$ \\
\hline Gift & $3(5)$ & -- & 2(4) & $1(2)$ & $5(5)$ & $1(1)$ \\
\hline Family land & $6(10)$ & $14(23)$ & 2(4) & $1(2)$ & $8(7)$ & $15(14)$ \\
\hline \multicolumn{7}{|l|}{ Farming experience } \\
\hline Minimum & 2 & 5 & 6 & 8 & 4 & 6.5 \\
\hline Maximum & 38 & 55 & 50 & 60 & 44 & 57.5 \\
\hline Mean & 21 & 25 & 26 & 31 & 23 & 28 \\
\hline \multicolumn{7}{|l|}{ Farm size (ha) } \\
\hline Minimum & 0.5 & 0.5 & 1 & 1 & 0.75 & 0.75 \\
\hline Maximum & 15 & 11 & 13 & 20 & 14 & 15.5 \\
\hline Mean & 4.78 & 4.96 & 4.47 & 5.57 & 4.62 & 5.26 \\
\hline \multicolumn{7}{|c|}{ Land size for groundnut production } \\
\hline Minimum & 0.5 & 0.5 & 0.5 & 0.3 & 0.5 & 0.4 \\
\hline Maximum & 8.5 & 13.5 & 4 & 5 & 6.25 & 9.25 \\
\hline Mean & 1.82 & 2.19 & 1.59 & 1.16 & 1.71 & 1.68 \\
\hline \multicolumn{7}{|l|}{ Value of farmlands } \\
\hline Minimum & 150,000 & 100,000 & 80,000 & 140,000 & 115,000 & 120,000 \\
\hline Maximum & $10,000,000$ & $6,000,000$ & $8,500,000$ & $12,000,000$ & $9,250,000$ & $9,000,000$ \\
\hline Mean & $1,940,000$ & $1,628,661$ & $2,247,300$ & $2,824,800$ & $2,093,650$ & $2,226,730$ \\
\hline
\end{tabular}

${ }^{*}$ ) $\%$ in parentheses; PLGA = Project LGAs; NPLGA = Non-project LGAs. 
Table 3. Contacts with extension services across the states.

\begin{tabular}{|c|c|c|c|c|c|c|}
\hline \multirow{3}{*}{ Variables } & \multicolumn{2}{|c|}{ Kebbi State } & \multicolumn{2}{|c|}{ Sokoto State } & \multicolumn{2}{|c|}{ Pooled Results } \\
\hline & PLGA & NPLGA & PLGA & NPLGA & PLGA & NPLGA \\
\hline & $\mathbf{F}(\%)$ & $\mathbf{F}(\%)$ & $\mathbf{F}(\%)$ & $F(\%)$ & $\mathbf{F}(\%)$ & $F(\%)$ \\
\hline \multicolumn{7}{|l|}{ Source of extension support } \\
\hline State ADP & $47(78)$ & $52(87)$ & $40(80)$ & $38(76)$ & $87(79)$ & $90(82)$ \\
\hline State Ministry of Agriculture & -- & -- & 1(2) & -- & $1(1)$ & -- \\
\hline Research institutes (IAR, CDA, etc.) & $9(15)$ & $4(7)$ & $9(18)$ & -- & $18(16)$ & $4(4)$ \\
\hline NGO & $3(5)$ & & & -- & $3(2.7)$ & \\
\hline Others & $1(2)$ & $4(7)$ & -- & 12(24) & $1(1)$ & $16(15)$ \\
\hline \multicolumn{7}{|l|}{ Frequency of extension support visits } \\
\hline Weekly & 2(3) & -- & $1(2)$ & -- & $3(2.7)$ & -- \\
\hline Bi-weekly & 2(3) & $12(20)$ & $11(22)$ & $7(14)$ & $13(12)$ & $19(17)$ \\
\hline Monthly & $46(77)$ & $36(60)$ & $35(70)$ & $38(76)$ & $81(74)$ & $74(67)$ \\
\hline Quarterly & $9(15)$ & $8(13)$ & 2(4) & $5(10)$ & $11(10)$ & 13(12) \\
\hline Others & $1(2)$ & $4(7)$ & $1(2)$ & & 2(2) & $4(4)$ \\
\hline \multicolumn{7}{|c|}{ Sources of credit for groundnut production } \\
\hline Banks & $1(2)$ & $4(7)$ & $6(12)$ & -- & $7(6)$ & $4(4)$ \\
\hline ADPs & $5(8)$ & $4(7)$ & $4(8)$ & -- & $9(8)$ & $4(4)$ \\
\hline Relatives & $11(18)$ & $10(17)$ & $1(2)$ & $6(12)$ & $12(11)$ & $16(15)$ \\
\hline Friends & $4(7)$ & 2(3) & $3(6)$ & $9(18)$ & $7(6)$ & $11(10)$ \\
\hline Community money lenders & $4(7)$ & 7(12) & 1(2) & 1(2) & $5(5)$ & $8(7)$ \\
\hline Government Credit Schemes & -- & -- & -- & -- & -- & -- \\
\hline NGOs & -- & -- & 2(4) & -- & $2(1.8)$ & -- \\
\hline Personal efforts & $35(58)$ & $33(55)$ & $33(66)$ & $4(68)$ & $68(62)$ & $67(61)$ \\
\hline
\end{tabular}

${ }^{*}$ ) Absolute values followed by percentages in parentheses.

Mignouna et al. (2011), reported direct relationships between technology adoption and access to extension services. As reported by Simtowe and Zeller (2006), access to credit is a determinant of the adoption of risky technologies given that credit eases liquidity constraints and household risk bearing abilities.

\section{Configuration of the adoption of improved groundnut technologies}

Table 4 shows that the varietal technologies (seed and seed management) being promoted are cultivated alongside a wide range of other groundnut varieties described as local in both PLGAs and NPLGAs. SAMNUT 24 is being grown by $39 \%$ of respondents in PLGAs and $19 \%$ of those in NPLGAs. Similarly, Kampala was reported to be a popular variety in PLGA (35\%) and NPLGA (40\%). Also, Yar Madali and Yar-dakar were common local varieties in PLGA and NPLGA of the two States.

Three groundnut varieties namely SAMNUT 24, Yar Madali and Ex-dakar are popular in both PLGA and NPLGA of the two States while the rest are location specific; such is the case with SAMNUT 26 and most of the local groundnut varieties. Despite sharing physical boundaries, not all the local groundnut varieties were common in both States; while Zabuwa, Bakar Anniya, etc. were reported only in Kebbi State, Bayal, Bazamfara, etc. were only reported in Sokoto State. Many of the groundnut varieties described as local, are attributed and recognized by the names of individuals (Kosoma, Yar Ula, Yar Jigila, etc.), colour of the kernel (Jar-gyada, Mai Atampa, Kampala, etc.), kernel shape (Mota, Haska, etc.), kernel size (Kwandala, Boleka, etc.), growth behaviour (Mai Jega, Tattabara, etc.), Tribe (Bahausa, Yar Gwari, etc.). Labels of registered and released crop varieties could disappear through a wide range of sociocultural transformations. Ex-dakar, for example, was officially endorsed in Nigeria from Senegal as SAMNUT 14.

This survey confirms that SAMNUT 24, Kampala and Ex-Dakar are most popular groundnut varieties in the two States. Due to their demonstrated features, SAMNUT 24, SAMNUT 25 and SAMNUT 26, proactive measures are being supported by the USAID funded Groundnut Scaling Project to sustain varietal purity. These measures include on-station re-evaluation by appropriate project 
Table 4. Groundnut varieties being grown by respondents in Sokoto and Kebbi States.

\begin{tabular}{|c|c|c|c|c|c|c|}
\hline \multirow{2}{*}{ Improved groundnut varieties } & \multicolumn{2}{|c|}{ Kebbi State } & \multicolumn{2}{|c|}{ Sokoto State } & \multicolumn{2}{|c|}{ Pooled Results } \\
\hline & PLGA & NPLGA & PLGA & NPLGA & PLGA & NPLGA \\
\hline Samnut-23 & $2(3)$ & - & -- & $1(2)$ & $2(2)$ & $1(1)$ \\
\hline Samnut-24 & $25(42)$ & 19(32) & $18(36)$ & $2(4)$ & $43(39)$ & $21(19)$ \\
\hline Samnut-25 & $3(5)$ & $1(2)$ & $1(2)$ & $2(4)$ & $4(4)$ & $3(3)$ \\
\hline Samnut-26 & 2(3) & - & $1(2)$ & -- & $3(3)$ & -- \\
\hline Samnut-23/24 & $4(7)$ & -- & $1(2)$ & -- & $5(5)$ & -- \\
\hline Samnut-24/25 & -- & -- & $6(12)$ & 1(2) & $6(6)$ & 1(11) \\
\hline Samnut-24/26 & 2(3) & -- & $3(6)$ & -- & $5(5)$ & -- \\
\hline Samnut-22/23/24 & 2(3) & -- & & -- & $2(2)$ & -- \\
\hline Samnut-23/24/25 & $4(7)$ & -- & $1(2)$ & -- & $5(5)$ & -- \\
\hline Samnut-23/24/26 & -- & $1(2)$ & $3(6)$ & -- & $3(3)$ & $1(1)$ \\
\hline Samnut-24/25/26 & $6(10)$ & -- & $15(30)$ & -- & $21(19)$ & -- \\
\hline Samnut-23/24/25/26 & $10(17)$ & -- & $1(2)$ & -- & $11(10)$ & -- \\
\hline \multicolumn{7}{|l|}{ Local groundnut varieties } \\
\hline Kampala & $23(38)$ & $37(62)$ & $15(30)$ & $7(14)$ & $38(35)$ & $44(40)$ \\
\hline Bahausa & -- & -- & $16(32)$ & $8(16)$ & & $8(7)$ \\
\hline Yar-Dakar & $19(32)$ & $11(18)$ & -- & $12(24)$ & $19(17)$ & $23(21)$ \\
\hline Yar Kosoma & -- & -- & -- & -- & & \\
\hline Yar Madali & $10(17)$ & 14(23) & $25(50)$ & 16(32) & $35(32)$ & $30(27)$ \\
\hline Kanannada & $6(10)$ & -- & -- & -- & $6(6)$ & \\
\hline Yar Maradi & $12(20)$ & $3(5)$ & -- & -- & $12(11)$ & $3(3)$ \\
\hline Yar Kwanche & $10(17)$ & $10(17)$ & -- & -- & $10(9)$ & $10(9)$ \\
\hline Yar Tsaye & $4(7)$ & -- & -- & -- & $4(4)$ & \\
\hline Markwai & $6(10)$ & $5(8)$ & -- & -- & $6(6)$ & $5(5)$ \\
\hline Mota & $11(18)$ & $5(8)$ & -- & -- & $11(10)$ & $5(5)$ \\
\hline Zabuwa & -- & $3(5)$ & -- & -- & -- & $3(3)$ \\
\hline Garo Garo & -- & $9(15)$ & -- & -- & -- & $9(8)$ \\
\hline Yar Ula & -- & $9(15)$ & -- & $8(16)$ & -- & $17(16)$ \\
\hline Farar Anniya & -- & $5(8)$ & -- & -- & -- & $5(5)$ \\
\hline Bakar Anniya & -- & $7(12)$ & -- & -- & -- & $7(6)$ \\
\hline Bayala & -- & -- & $1(2)$ & -- & -- & -- \\
\hline Yar Tambuwal & -- & -- & $1(2)$ & -- & -- & -- \\
\hline Yar Tsungune & -- & -- & $4(8)$ & -- & -- & -- \\
\hline Yar Gidima & -- & -- & $9(18)$ & -- & -- & -- \\
\hline Mai Wada & -- & -- & $10(20)$ & -- & -- & -- \\
\hline Yar Kasa & -- & -- & -- & $2(4)$ & -- & $2(2)$ \\
\hline Bazamfara & -- & -- & -- & $12(24)$ & -- & $12(11)$ \\
\hline
\end{tabular}

$\left({ }^{*}\right)$ Absolute values followed by percentages in parentheses.

implementation partners, back-stopping of private seed companies in the production and distribution of Foundation Seeds, enhanced certification by the National Agricultural Seeds Council (NASC), continual awareness and targeted trainings of value chain actors by ICRISAT and NASC.

Likewise, Table 5 outlines the extent of utilisation of both the varietal and accompanying crop and aflatoxin management practices being promoted in both Sokoto and Kebbi States. The pooled results show that mean update rates for varietal technologies (the seed) is $81 \%$ in PLGA compared to $19 \%$ in NPLGA. Similarly, mean update rate of on-farm management practices is $76 \%$ in PLGA as against $24 \%$ in NPLGA, the mean uptake of post-harvest management technologies is 75\% in PLGA compared to $25 \%$ in NPLGA. This trend is consistent for all individual technologies related to varietal technologies and accompanying crop and aflatoxin management practices in the two States. These results are similar to those reported by Vabi et al. (2019) in the other three 
Table 5. Summary of the adoption of recommended groundnut technologies in study states.

\begin{tabular}{|c|c|c|c|c|c|c|c|c|c|c|}
\hline \multirow[b]{2}{*}{ Category 1: Seed and seed management } & \multicolumn{2}{|c|}{ PLGA Kebbi State } & \multicolumn{2}{|c|}{ NPLGA Kebbi State } & \multicolumn{2}{|c|}{ PLGA Sokoto State } & \multicolumn{2}{|c|}{ NPLGA Sokoto State } & \multicolumn{2}{|c|}{ Both States } \\
\hline & Adopters & $\begin{array}{c}\text { Non- } \\
\text { Adopters }\end{array}$ & Adopters & $\begin{array}{c}\text { Non- } \\
\text { Adopters }\end{array}$ & Adopters & $\begin{array}{c}\text { Non- } \\
\text { Adopters }\end{array}$ & Adopters & $\begin{array}{c}\text { Non- } \\
\text { Adopters }\end{array}$ & Adopters & $\begin{array}{c}\text { Non- } \\
\text { Adopters }\end{array}$ \\
\hline - Use improved groundnut varieties & $60(100)$ & -- & $54(90)$ & $6(10)$ & $47(94)$ & $3(6)$ & $11(22)$ & $39(78)$ & 172(78) & $48(22)$ \\
\hline - Shell seeds during planting season & $56(93)$ & $4(7)$ & $50(83)$ & $10(17)$ & $42(84)$ & $8(16)$ & $37(74)$ & $13(26)$ & 185(84) & $35(16)$ \\
\hline - Sort and clean seeds before planting & $54(90)$ & $6(10)$ & $50(83)$ & $10(17)$ & $43(86)$ & $7(14)$ & $35(70)$ & $15(30)$ & 182(83) & $38(17)$ \\
\hline - Treat seeds before planting & $54(90)$ & $6(10)$ & $48(80)$ & $12(20)$ & $40(80)$ & $10(20)$ & $32(64)$ & $18(36)$ & $174(79)$ & $46(21)$ \\
\hline Means & $56(93)$ & $4(7)$ & $50(84)$ & 10(16) & $43(86)$ & $7(14)$ & $29(58)$ & $21(42)$ & 178(81) & $42(19)$ \\
\hline \multicolumn{11}{|l|}{ Category 2: On farm management practices } \\
\hline - Use farms with sandy-loamy soils & $60(100)$ & -- & $47(78)$ & $13(22)$ & $47(94)$ & $3(6)$ & $46(92)$ & $4(8)$ & $200(91)$ & 20(9) \\
\hline - Till/ridge farms before planting & $60(100)$ & -- & $47(78)$ & $13(22)$ & $50(100)$ & -- & $40(80)$ & $10(20)$ & 197(90) & $23(10)$ \\
\hline - Sow at $10 \mathrm{~cm} \times 75 \mathrm{~cm} / 2 \mathrm{SH}$ & $40(67)$ & 20(33) & $31(52)$ & $29(48)$ & $37(74)$ & 13(26) & $24(48)$ & $26(52)$ & $133(60)$ & $88(40)$ \\
\hline - Sow at $20 \mathrm{~cm} \times 75 \mathrm{~cm} / 2 \mathrm{SH}$ & $49(82)$ & $11(18)$ & $36(60)$ & $24(40)$ & $36(72)$ & $14(28)$ & $28(56)$ & $22(44)$ & 149(68) & $71(32)$ \\
\hline - Use Farm Yard Manure (FYM) & $50(83)$ & $10(17)$ & $42(70)$ & $18(30)$ & $41(82)$ & $9(18)$ & $38(76)$ & $12(24)$ & 161(73) & $59(27)$ \\
\hline - Apply SSP (2 bags/ha and NPK I bag/ha), & $50(83)$ & $10(17)$ & $32(53)$ & $28(47)$ & $44(88)$ & $6(12)$ & $38(76)$ & $12(24)$ & $154(70)$ & $66(30)$ \\
\hline $\begin{array}{l}\text { - Remove physically weak stands/weeds and off- } \\
\text { types }\end{array}$ & $58(97)$ & $2(3)$ & $41(68)$ & $19(32)$ & $48(96)$ & $2(4)$ & $36(72)$ & $14(28)$ & 183(83) & $37(17)$ \\
\hline - Spray with appropriate pesticide & $49(82)$ & $11(18)$ & $29(48)$ & $31(52)$ & $32(64)$ & $18(36)$ & $33(66)$ & $17(34)$ & 143(65) & $77(35)$ \\
\hline Means & $53(89)$ & $7(11)$ & $37(63)$ & $23(37)$ & $43(86)$ & $7(14)$ & $35(71)$ & $15(29)$ & $167(76)$ & $53(24)$ \\
\hline \multicolumn{11}{|l|}{ Category 3: Post-harvest Management practices } \\
\hline - Lift pods when mature (85 - 90 days) & $58(97)$ & $2(3)$ & $21(35)$ & $39(65)$ & $48(96)$ & $2(4)$ & $34(68)$ & $16(32)$ & 161(73) & $59(27)$ \\
\hline - Dry pods on-farm between 5 -7 days after lifting & $54(90)$ & $6(10)$ & $29(48)$ & $31(52)$ & $44(88)$ & $6(12)$ & $35(70)$ & $15(30)$ & $162(74)$ & $58(26)$ \\
\hline - Shake pods for moisture contents before stripping & $58(97)$ & 2(3) & $17(29)$ & $43(71)$ & $50(100)$ & -- & $43(86)$ & $7(14)$ & 168(76) & $52(24)$ \\
\hline - Store pods in clean in ventilated stores & $52(87)$ & $8(13)$ & $34(57)$ & $26(43)$ & $45(90)$ & $5(10)$ & $41(82)$ & $9(18)$ & 177(78) & $48(22)$ \\
\hline Means & $55(92)$ & $5(8)$ & $25(42)$ & $35(58)$ & $47(94)$ & $3(6)$ & $38(76)$ & $12(24)$ & $166(75)$ & $54(25)$ \\
\hline
\end{tabular}

$\left({ }^{*}\right)$ Absolute value followed by percentage in parentheses.

States where the project is also being implemented.

The mean adoption rates of improved groundnut varieties contrast with the findings of McGuire and Sperling (2015), Bezner-Kerr (2013), Cavatassi et al. (2011) and Guei et al. (2011) where they demonstrate that farmers' saved seeds constitute the foremost source of seeds sown by African farmers. Targeted and persistent awareness and capacity building actions could improve and sustain the use of both varietal and crop management practices.
Overall, the adoption rates of non-varietal technologies or accompanying crop management practices are encouraging - these vary from $60 \%$ for sowing at $10 \mathrm{~cm} \times 75 \mathrm{~cm}$ to $91 \%$ for selecting sites with potentials of better fertility. Alene et al. (2006) argued that adoption of non-varietal 
technologies is imperative for varietal technologies to fully express their genetic potentials. Also, as explained by Ajeigbe et al. (2016), farmers in West Central Africa (WCA) plant grain crops in rows spaced at $75 \mathrm{~cm}$ because most tractors and animal drawn ridgers are fixed at widths of $75 \mathrm{~cm}$ between row spacing. In Nigeria, this practice was upheld as a recommended practice of 75 $\mathrm{cm} \times 20 \mathrm{~cm}$. Indeed, Nigam et al. (2006) opined that optimum plant spacing is key to higher yields in groundnut. Combining improved groundnut varieties with appropriate fertilizers and optimum plant densities could increase groundnut productivity and profitability of smallholder farmers in WCA. It is known that the use of adequate doses of appropriate fertilizers enhance root development and improve the availability of required nutrients for all crops including groundnut. As recurrently pointed out by Ndjeunga et al. (2006), Ndjeunga et al. (2011) and Ndjeunga (2012), differences in groundnut productivity in WCA can also be explained by insufficient and unsuitable uses of inputs.

In addition to the use of improved groundnut varieties alongside appropriate crop management practices, a number of post-harvests practices from the pooled results are signals of the adoption post-harvest measures to mitigate the development of aflatoxin producing fungi in PLGA. These include: lifting groundnut when mature ( $73 \%$ of respondents), adequate drying $(71 \%$ of respondents), shaking of pods to check dryness before stripping and bagging (78\% of respondents), adequate storage $(75 \%$ of respondents).

\section{Determinants of the adoption of groundnut technologies}

The three (3) categories of factors driving the adoption of groundnut technologies emerged from the Sokoto and Kebbi State survey (Table 6). These are:

Category 1: Farming experience positively influenced the use of improved groundnut varieties (UIGV), first weeding at between three and four weeks (FW3$4 \mathrm{~W}$ ), drying pods on-farms for between five and seven days (DPO5-7D) at $5 \%$ level of significance, while the application of fertilizers (SSP and NPK) was statistically significant at $1 \%$.

Category 2: Level of education positively influenced the adoption of use of improved groundnut varieties, (UIGV) and planting at $10 \mathrm{~cm} \times 75 \mathrm{~cm}(10 \mathrm{~cm} \times 75 \mathrm{~cm} / 2 \mathrm{SH})$ at 5 $\%$ level of significance while treating seeds before planting (TSBP) was statistically significant at $1 \%$.

Category 3: Household size positively influenced adoption of shelling seeds during the planting season (SSPS), planting at $10 \mathrm{~cm} \times 75 \mathrm{~cm} / 2 \mathrm{SH}(10 \mathrm{~cm} \times 75$ $\mathrm{cm} / 2 \mathrm{SH}$ ) and second weeding at between six and eight weeks (SW6 -8W) at 5\% level of significance while shelling seeds before planning (SSBP), planting at $20 \mathrm{~cm}$ $\times 75 \mathrm{~cm}(20 \mathrm{~cm} \times 75 \mathrm{~cm} / 2 \mathrm{HS})$ and lifting pods when mature (LP85-90) $(10 \%$,$) were statistically significant at$ $1 \%$.

Adoption studies of crop and livestock technologies have not deliberately isolated the seed (or breed) component from accompanying management practices during technology promotion stages. This trend limits prospects for setting subsequent research agendas, providing feedback for setting agenda for delivery research and demonstration of the totality of the benefits of research products. Nevertheless, a plethora of adoption studies have confirmed the combined effects of farming experience, age, household size, education, access to information, credit and extension services, etc. on enduser's adoption decisions. Recent cases in point are the studies of Dhraief et al. (2018), Muhammad (2015), Mbavai et al. (2015), Bello et al. (2011), James, (2014), Adzawla et al. (2016), Idoko and Sabo (2014), Melesse (2015) and Loevinsohn et al. (2013).

Muhammad (2015) and Bello et al. (2011) reported that farming experience positively and significantly influenced the adoption of agricultural technologies. The outcomes of this survey on education and household size are in line with the findings of James (2014) who reported household size to the adoption of groundnut productivity enhancement technologies.

According to Mignouna et al. (2011) and Lavison (2013), education increases end-users' abilities to obtain, process and use information relevant to the adoption of technologies. Also, Mignouna et al. (2011) considered household size to influence the adoption of recommended agricultural technologies given that large household sizes ease labour requirements for sowing, weeding, lifting, stripping and shelling of groundnut. The combined results in Table 7, for example, shows that paid labour is the main source of labour for groundnut production in PLGA accounting for about $45 \%$ with a combination of paid and family labour accounting for about half of labour requirements. Child labour constitutes an important source of farm labour for groundnut production in both PLGA and NPLGA; male children account for slightly more than female children in both PLGA and NPLGA (Table 7).

\section{Estimated financial gains from groundnut production in the study states}

Table 8 summarises the operational (variable) costs and revenue generated from producing groundnuts in PLGAs and NPLGAs. The operational cost comprises seeds, fertilizers, and pesticides, seasonal rents for farm land, farm labour and transportation of produce from the farms to house of groundnut producing households. The pooled 
Table 6. Determinants of adoption of groundnut technologies (Seeds, accompanying crop management practices and aflatoxin).

\begin{tabular}{|c|c|c|c|c|c|c|c|c|c|c|}
\hline \multirow{2}{*}{$\begin{array}{l}\text { Variables } \\
\text { Improved groundnut varieties (Seeds) }\end{array}$} & \multicolumn{2}{|c|}{ UIGV } & \multicolumn{2}{|c|}{ SSPS } & \multicolumn{2}{|c|}{ SSBP } & \multicolumn{2}{|c|}{ TSBP } & & \\
\hline & Coeff. & Sign. & Coeff. & Sign. & Coeff. & Sign. & Coeff. & Sign. & & \\
\hline - Farming experience & 0 & $0.041^{* *}$ & 0.065 & 0.414 & 0.017 & 0.694 & 0.046 & 0.247 & & \\
\hline - Age & -0.299 & 0.815 & -0.535 & 0.646 & 0.073 & 0.908 & -0.097 & 0.864 & & \\
\hline - Level of education & 1.208 & $0.015^{\star *}$ & -0.329 & 0.453 & 0.22 & 0.321 & -0.001 & $0.003^{\star * *}$ & & \\
\hline - Household size & -0.034 & 0.762 & 0.064 & $0.049^{* *}$ & -0.012 & $0.004^{*}$ & -0.019 & 0.725 & & \\
\hline \multirow[t]{2}{*}{ Constant } & -8.478 & 0.126 & -2.653 & 0.392 & -3.484 & 0.057 & -2.436 & 0.112 & & \\
\hline & \multicolumn{2}{|c|}{ UFSLS } & \multicolumn{2}{|c|}{ TRBP } & \multicolumn{2}{|c|}{$10 \mathrm{~cm} \times 75 \mathrm{~cm} / 2 \mathrm{SH}$} & \multicolumn{2}{|c|}{$20 \mathrm{~cm} \times 75 \mathrm{~cm} / 2 \mathrm{SH}$} & FYM & \\
\hline On-farm crop management practices & Coeff. & Sign. & Coeff. & Sign. & Coeff. & Sign. & Coeff. & Sign. & Coeff. & Sign. \\
\hline - Farming experience & -0.081 & 0.305 & 0.017 & 0.694 & 0.035 & 0.274 & -0.024 & 0.371 & -0.024 & 0.371 \\
\hline - Age & 0.745 & 0.563 & 0.073 & 0.908 & -0.183 & 0.687 & -0.048 & 0.915 & -0.048 & 0.915 \\
\hline - Level of education & 0.045 & 0.923 & 0.22 & 0.321 & 0.292 & $0.048^{* *}$ & 0.021 & 0.897 & 0.021 & 0.897 \\
\hline - Household size & -0.054 & 0.686 & -0.012 & 0.841 & -0.094 & $0.043^{\star *}$ & 0.049 & $0.000^{* * *}$ & 0.049 & 0.241 \\
\hline \multirow[t]{2}{*}{ Constant } & -3.64 & 0.298 & -3.484 & 0.057 & -1.276 & 0.289 & -1.245 & 0.304 & -1.245 & 0.304 \\
\hline & \multicolumn{2}{|c|}{ SSP and NPK } & \multicolumn{2}{|c|}{ FW3-4W } & \multicolumn{2}{|c|}{ SW6-8W } & \multicolumn{2}{|c|}{ RPWS } & \multicolumn{2}{|c|}{ SAP } \\
\hline On-farm crop management practices & Coeff. & Sign. & Coeff. & Sign. & Coeff. & Sign. & Coeff. & Sign. & Coeff. & Sign. \\
\hline - Farming experience & -0.02 & $0.003^{\star * \star}$ & -0.052 & $0.053^{\star *}$ & -0.116 & 0.247 & -0.042 & 0.577 & 0.029 & 0.333 \\
\hline - Age & -0.005 & 0.992 & 0.891 & 0.497 & 0.64 & 0.618 & -0.354 & 0.775 & -0.487 & 0.281 \\
\hline - Level of education & 0.008 & 0.967 & -0.319 & 0.563 & 0.759 & 0.076 & 1.026 & 0.077 & -0.02 & 0.893 \\
\hline - Household size & 0.013 & 0.802 & -0.165 & 0.364 & -0.345 & $0.031^{* *}$ & -0.12 & 0.295 & -0.012 & 0.774 \\
\hline Constant & -1.508 & 0.291 & -2.184 & 0.541 & -2.658 & 0.406 & -5.139 & 0.185 & -0.223 & 0.846 \\
\hline Variables & & $5-90$ & DP & $5-7 D$ & & & & VA & & \\
\hline Post-harvest management practices & Coeff. & Sign. & Coeff. & Sign. & Coeff. & Sign. & Coeff. & Sign. & & \\
\hline - Farming experience & -0.085 & 0.148 & -0.085 & $.017^{\star *}$ & 0.217 & 0.207 & -0.002 & 0.948 & & \\
\hline - Age & 0.142 & 0.683 & 0 & 0.998 & 1.091 & 0.142 & -0.097 & 0.643 & & \\
\hline - Level of education & -0.087 & 0.928 & 0.09 & 0.879 & -5.279 & 0.535 & 0.015 & 0.98 & & \\
\hline - Household size & -0.011 & $0.000^{\star * *}$ & 0.01 & 0.859 & -0.336 & 0.161 & -0.008 & 0.884 & & \\
\hline Constant & -1.789 & 0.447 & -0.612 & 0.683 & -0.088 & 0.996 & -1.53 & 0.327 & & \\
\hline
\end{tabular}

UIGV: Use improved groundnut varieties; SSPS: Shell seeds during planting season; SSBP: Sort and clean seeds before planting; TSBP: Treat seeds before planting. UFSLS= Use farms with sandy-loamy soils; TRBF=Till/ridge farms before planting; $10 \mathrm{~cm} \times 75 \mathrm{~cm} / 2 \mathrm{SH}=\mathrm{Sow}$ at $10 \mathrm{~cm} \times 75 \mathrm{~cm} / 2 \mathrm{seeds} / \mathrm{hole}, \mathrm{Sow}$ at $20 \mathrm{~cm} \times 75 \mathrm{~cm} / 2 \mathrm{SH}=20 \mathrm{~cm} \times 75 \mathrm{~cm} / 2 \mathrm{SH}, \mathrm{FYM}=\mathrm{Use}$ Farm Yard Manure; SSP and NPK = Apply SSP (2 bags/ha and NPK I bag/ha), FW3-4W = First weeding at 3-4 weeks after sowing, SW6-8W = Second weeding 6-8 weeks after sowing, RPWS=Remove physically weak stands/weeds and off-types; SAP =Spray with appropriate pesticide, LP85-90D = Lift pods when mature;DPF5-7D = Dry pods on-farm between 5-7 days after lifting, SPMC= Shake pods for moisture contents before stripping, SPVS = Store pods in ventilated areas.

results show that the cost of farm labour compares closely with the cost of other farm inputs; $48 \%$ compared to $43 \%$ in PLGA and NPLGA, respectively.

Annual Gross Profit Margin (GPM) in PLGAs and NPLGA were 66,854 Naira (or \$219) and 23,744 Naira (or $\$ 78$ ), respectively, indicating that by adopting improved technologies, smallholder farmers could make about $64 \%$ additional cash incomes. Returns per Naira invested are $70 \%$ in
PLGAs and $30 \%$ in NPLGAs, suggesting that by adopting improved groundnut technologies, smallholder farmers in the two States could increase farm-level production and productivity. Whether in PLGAs or NPLGAs, cost efficiency 
Table 7. Sources and categories of farm labour employed in groundnut production.

\begin{tabular}{|c|c|c|c|c|c|c|}
\hline \multirow{3}{*}{ Variable } & \multicolumn{2}{|c|}{ Kebbi State } & \multicolumn{2}{|c|}{ Sokoto State } & \multicolumn{2}{|c|}{ Pooled results } \\
\hline & PLGA & NPLGA & PLGA & NPLGA & PLGA & NPLGA \\
\hline & $F(\%)$ & $F(\%)$ & $\mathbf{F}(\%)$ & $F(\%)$ & $F(\%)$ & $\mathbf{F}(\%)$ \\
\hline \multicolumn{7}{|c|}{ Sources of farm labor } \\
\hline Paid & 14(23.3) & $9(15)$ & $35(70)$ & $23(46)$ & $49(45)$ & $32(29)$ \\
\hline Family & $1(1.7)$ & $5(8.3)$ & $3(6)$ & $5(10)$ & $4(3.6)$ & $10(4)$ \\
\hline Paid and family & $45(75)$ & $46(76.7)$ & $12(24)$ & $22(44)$ & $57(52)$ & $68(52)$ \\
\hline \multicolumn{7}{|c|}{ Farm-labor by sex } \\
\hline Adult male & $59(98)$ & $60(100)$ & $50(100)$ & $49(98)$ & $109(99)$ & $109(99)$ \\
\hline Male child & $48(80)$ & $54(90)$ & $27(54)$ & $39(78)$ & $75(68)$ & $93(85)$ \\
\hline Adult female & $45(75)$ & $50(83)$ & $31(62)$ & $13(26)$ & $76(69)$ & $63(57)$ \\
\hline Female child & $33(55)$ & $39(65)$ & $16(32)$ & $4(8)$ & $49(43)$ & $43(39)$ \\
\hline
\end{tabular}

(*) Absolute values followed by percentages in parentheses.

Table 8. Profitability of groundnut production in the study states (2017 cropping season)

\begin{tabular}{|c|c|c|c|c|c|c|}
\hline \multirow{2}{*}{ Cost component } & \multicolumn{2}{|c|}{ Kebbi State } & \multicolumn{2}{|c|}{ Sokoto State } & \multicolumn{2}{|c|}{ Pooled Results } \\
\hline & PLGA & NPLGA & PLGA & NPLGA & PLGA & NPLGA \\
\hline \multicolumn{7}{|c|}{ Expenses on farm inputs (except farm labour) } \\
\hline Seeds $(\mathrm{kg})$ & $15,479(18)$ & $18,712(21)$ & $18,960(20)$ & $15,985(19)$ & $17,219(19)$ & $17,348(20)$ \\
\hline Fertilizers (kg) & $16,845(19)$ & $13,908(15)$ & $14,853(16)$ & $12,405(14)$ & $15,849(18)$ & $13,157(15)$ \\
\hline Pesticides (Litre) & $650(1)$ & $137(0)$ & $1,568(12)$ & $900(1)$ & $11,09(1)$ & $5,18(1)$ \\
\hline Farm Yard Manure (kg) & $6,990(8)$ & $4,520(5)$ & $83,98(9)$ & $4,823(6)$ & $7,694(9)$ & $4,671(5)$ \\
\hline Transport Cost of Pods (N/100 kg bag) & $1,818(2)$ & $2,946(3)$ & $1,829(2)$ & $2,118(2)$ & $1,824(2)$ & $2,532(3)$ \\
\hline Transport Cost of fodder (N/100 kg bag) & $2,035(2)$ & $18,839(2)$ & $1,560(2)$ & $17,38(2)$ & $1,798(2)$ & $1,810(2)$ \\
\hline Purchase of bags For Storage (N/bag) & $2,123(2)$ & $2,967(3)$ & $2,683(3)$ & $4,111(5)$ & $2,403(3)$ & $3,539(4)$ \\
\hline Sub-total(a) & 45,940 & 45,072 & 49,850 & 42,080 & 47,895 & 43,576 \\
\hline \multicolumn{7}{|c|}{ Expenses of farm labor for different farm operations } \\
\hline Land preparation & $7,472(9)$ & $11,540(13)$ & $5,483(6)$ & $9,947(12)$ & $6,478(7)$ & $10,743(12)$ \\
\hline Planting & $4,902(6)$ & $9,177(10)$ & $6,641(7)$ & $5,769(7)$ & $5,771(6)$ & $7,473(8)$ \\
\hline Fertilizer Application & $1,805(2)$ & $1,933(2)$ & $2,026(2)$ & $3,577(4)$ & $19,15(2)$ & $2,755(3)$ \\
\hline Weeding & $12,031(14)$ & $11,873(13)$ & $14,257(15)$ & $12,813(15)$ & $13,144(15)$ & $12,343(14)$ \\
\hline Harvesting & $15,528(18)$ & $11,499(13)$ & $15,020(16)$ & $12,330(14)$ & $15,274(17)$ & $11,914(13)$ \\
\hline Sub-total(b) & 41,739 & 46,022 & 43,427 & 44,436 & 42,583 & 45,229 \\
\hline
\end{tabular}


Table 8. Continues.

\begin{tabular}{|c|c|c|c|c|c|c|}
\hline Total operational cost $(a+b)$ & 87,678 & 91,094 & 93,277 & 86,516 & 90,478 & 88,805 \\
\hline Average output (kg/ha) & 1,080 & 851 & 1,042 & 818 & 1,061 & 834 \\
\hline Average price (N/kg) & 123 & 130 & 175 & 140 & 149 & 135 \\
\hline Total revenue & 132,608 & 110,189 & 182,055 & 114,908 & 157,332 & 112,549 \\
\hline Gross Profit Margin (GPM) & 44,929 & 19,096 & 88,778 & 28,392 & 66,854 & 23,744 \\
\hline Returns per Naira invested & 0.5 & 0.2 & 1 & 0.3 & 0.7 & 0.3 \\
\hline
\end{tabular}

$\left(^{*}\right)$ Absolute values followed by percentage in parentheses.

can be improved by improving plant population densities (planting at $10 \mathrm{~cm} \times 75 \mathrm{~cm}$ ), close follow-up of the sources and different categories of farm labour (substituting paid labour with family labour), identifying and recruiting more efficient farm labour, working on the number of persons handling different farm operation, etc. While demonstrating that groundnut production is a source of cash and non-cash incomes, a tactful combination of hired and family labour and/or male/female farm labour, could help the smallholder farmer move onto more cost effective combinations. Similarly, efficiency on the cost of production can be reduced through securing discounts on bulk purchase of inputs by farming groups and/or annual tactful increases in market prices of certified seeds. This study revealed that only 88 and $37 \%$ of respondents belong to farming groups in PLGA and NPLGA, respectively.

\section{CONCLUSION}

Despite the national and socio-economic importance of groundnut to the Nigerian economy, productivity of the crop is lower (about $1.2 \mathrm{t} / \mathrm{ha}$ ) compared to global means of between 1.7 and over 3 tons per ha in the USA and China. Prospects for improving the productivity of the crop exist through the adoption of both varietal and non-varietal technologies of the crop. Amongst other things, this paper has presented outcomes of a survey to determine the adoption of groundnut varietal and non-varietal technologies in Sokoto and Kebbi States of North-western Nigeria. Outcomes of the survey show that the improved groundnut varieties being scaled out are cultivated alongside a wide range of local varieties in both PLGA and NPLGA. Three (3) categories of complementary factor drive the adoption of both varietal and nonvarietal technologies: farming experience, level of education and household size. The positive values of both the gross profit margin and returns on naira invested point to the fact that by adopting varietal and non-varietal technologies, smallholder farmers could make up to $64 \%$ additional cash incomes. In terms of returns on investment, by adopting improved groundnut technologies, smallholder farmers can expect to earn nearly forty kobo per season for each naira invested.

\section{ACKNOWLEDGEMENTS}

This study was carried out with Funds provided to ICRISAT by USAID - United States Agency for International Development within the framework of the implementation of a regional project dubbed "Increasing Groundnut Productivity of Smallholder
Farmers in Mali, Ghana and Nigeria". The authors are grateful to all Project Desk Officers and Extension Agents of the Agricultural and Rural Development Projects/Authorities (ADPs) of Sokoto and Kebbi States and all the farmers who accepted to participate in these surveys.

\section{REFERENCES}

Adzawla W, Donkoh SA, Nyarko G, O'Reilly PJ, Olayide OE, Mayes S, Feldman A, Azman HR, 2016. Adoption of Bambara groundnut production and its effects on farmers' welfare in Northern Ghana. Afr J Agric Res, 11(7): 583-594.

Ajeigbe $A H$, Kamara AY, Kunihya A, Inuwa AH, Adinoyi A, 2016. Response of groundnut to plant density and phosphorous application in the Sudan Savanna zone of Nigeria. Int J Biosci, 9(1): 291-302.

Ajeigbe HA, Waliyar F, Echekwu CA, Ayuba K, Motagi, BN, Eniayeju D, Inuwa A, 2015. A Farmer's Guide to Groundnut Production in Nigeria.502 324, ICRISAT.

Akudugu M, Guo E, Dadzie S, 2012. Adoption of modern agricultural production technologies by farm households in Ghana: What factors influence their decisions? J Biol Agric Healthcare, 2(3): 1-13

Alene AD, Manyong VM, Gockowsky J, Coulibaly O, Abele S, 2006. A framework for conceptualizing impact assessment and promoting impact culture in agricultural research. Impact series. International Institute for Tropical Agriculture (IITA). Ibadan, Nigeria. $30 \mathrm{pp}$.

Bello M, Dauda S, Okwu OJ, 2011. Determinants for the adoption of farming technologies in Jenkwe development area of Nasarawa State, Nigeria. J Environ Issues Agric Dev Countries, 3(1): 65-71.

Bezner-Kerr R, 2013. Seed struggles and food sovereignty in 
Northern Malawi. J Peasant Stud, 40(5): 867-897.

Cavatassi R, Lipper L, Narloch U, 2011. Modern variety adoption and risk management in drought prone areas: insights from the sorghum farmers of eastern Ethiopia. Agric Econ, 42(3): 279-292.

Chianu JN, Tsujii H, 2004. Determinants of farmers' decision to adopt or not adopt inorganic fertilizer in savannas of Northern Nigeria. Nutrient Cycling in Agroecosyst, 70: 293-301.

Dhraief MZ, Bedhiaf-Romdhania S, Dhehibib B, Oueslati-Zlaouia M, Jebali O, Ben-Youssef S, 2018. Factors affecting the adoption of innovative technologies by livestock farmers in arid area of Tunisia. FARA Research Report, 3(5): 22.

Dodo BA, 1996. Sokoto Agricultural Development Project: History of SADP Successes from Enclave to Multi-project Status. Planning, Monitoring and Evaluation Unit.

Doss CR, 2003. Understanding Farm Level Technology Adoption: Lessons Learned from CIMMYT's Micro-surveys in Eastern Africa. CIMMYT Economics Working Paper 03-07. Mexico, D.F.: CIMMYT.

Echekwu CA, Ntare BN, Alhassan U, Mohammed,SG, Alabi O, 2012. Proposal for Registration and Release of ICIAR 19BT (SAMNUT 24) as a new Grondnut Variety in Nigeria.

Edwards JB, 2016. Modern gross profit analysis. J Corporate Account Finance. 27(4): 45-55

FAO - Food and Agricultural Organization (2017). FAOSTAT Production Year 2017.

Guei RG, Barra A, Drissa S, 2011. Promoting smallholder seed enterprises: quality seed production of rice, maize, sorghum and millet in northern Cameroon. Int J Agric Sustainability, 9(1): 91-99.

Ibrahim U, Ayinde BT, Dauda H, Mukhtar AA, 2012. Socio-economic factors affecting groundnut production in Sabongari Local Government of Kaduna State, Nigeria. Int J Food Agric Econ, 1(1): 41-48.

James OA, 2014. Household size and agricultural land-use pattern in Obagaji area of the Guinea Savanna region. Nig J Agric Extension Rural Dev, 6(1): 48-54.

Kariyasa K, Dewi A, 2011. Analysis of factors affecting adoption of integrated crop management farmer field school in swampy areas. Int J Food Agric Econ, 1(2): 29-38.

Kassie M, Shiferaw B, Muricho G, 2010. Adoption and Impact of Improved Groundnut Varieties on Rural Poverty: Evidence from Rural Uganda. Environment for Development (EfD) Discussion Paper 1011.

Lavison $R$, 2013. Factors Influencing the Adoption of Organic Fertilizers in Vegetable Production in Accra, M.Sc Thesis, Accra Ghana.

Loevinsohn M, Sumberg J, Diagne A, 2013. Under what circumstances and conditions does adoption of technology result in increased agricultural productivity? Protocol. London: EPPI Centre, Social Science Research Unit, Institute of Education, University of London.

Mwangi M, Kariuk S, 2015. Factors determining adoption of new agricultural technology by smallholder farmers in developing countries. J Econ Sustain Dev, 6(5): 208-216.

Mauceri M, Alwang J, Norton G, Barrera V, 2005. Adoption of Integrated Pest Management Technologies: A Case Study of Potato Farmers in Carchi, Ecuador; Selected Paper prepared for presentation at the American Agricultural Economics Association Annual Meeting, Providence, Rhode Island, July 24-27, 2005.

Mbavai JJ, Shitu MB, Abdoulaye T, Kamara AY, Kamara SM, 2015. Patterns of adoption and constraints to adoption of cowpea varieties in the Sudan Savanna Zone of Northern Nigeria. J Agric Extension Rural Dev, 7(12): 322-329.

McGuire S, Sperling L, 2015. Seed systems smallholder farmers use. Food Security, 8(1): 179-195.

Meless TM, 2015. Agricultural Technology Adoption and Market Participation under Learning Externality: Impact Evaluation on Smallscale Agriculture from Rural Ethiopia Maastricht School of Management. Working Paper 2015/06.

Mignouna B, Manyong M, Rusike J, Mutabazi S, Senkondo M, 2011. Determinants of adopting of maize technology and its impact on household income in Western Kenya. AgBioforum, 14(3): 158-163.
Muhammad H, 2015. Determinants of Inputs Demand and Adoption of Grains Legumes and Associated Technologies of N2Africa in Kano State Nigeria: Unpublished M.Sc. Dissertation, Department of Agricultural Economics and Extension, Bayero University of Kano.

NACGRB - National Centre for Genetic Resources and Biotechnology (2014). Catalogue of Crop Varieties Released and Registered in Nigeria. Volume 8. Updated as of September 2014.Pp 19-21.

NAERLS - National Agricultural Research and Extension Liaison Services, 2017. Agricultural Performance Survey of the 2014 wet season in Nigeria. ISSN: 2408-7459

Ndjeunga J, Umar J, Ahmed B, Aba A, Ibro A, Abdiulaye A, Gwadi K, 2011. Adoption and impacts of modern sorghum and pearl millet varieties in Northern Nigeria. ICRISAT Working Paper

Ndjeunga JB, Ntare BR, Waliyar F. and Ramouch (eds), 2006. Groundnut seed systems in West Africa. CFC Technical Paper Number 40. P.O. Box 74656, 1070 BR Amsterdam; The Netherlands Common Fund for Commodities; and ICRISAT Patancheru 502 324, Andra Prades, India. $232 \mathrm{pp}$.

Ndjeunga JB, Ntare R, Ajiegbe AH, Echekwu CA, Ibro A, Amadou A, 2012. Adoption and impacts of modern groundnut varieties in Nigeria. Technical report, submitted to ICRISAT.

Ng'ombe J, Kalinda T, Tembo G, Kuntashula E, 2014. Econometric analysis of the factors that affect Adoption of conservation farming practices by smallholder farmers in Zambia. J Sustain Dev, 7(4): 124138.

Nigam SN, Aruna R, Giri DY, Ranga-Rao GV, Reddy AGS, 2006. Obtaining sustainable higher groundnut yields: Principle and practices of cultivation. International Crops Research Institute for the Semi-Arid Tropics (ICRISAT). Patancheru 502 324, Andra Pradesh, India.

Population Census Report of Kebbi and Sokoto State (2006). National Population Commission, Census Reports.

Simtowe F, Asfaw S, Diagne A, Shiferaw B, 2008. Determinants of Agricultural Technology adoption: the case of improved groundnut varieties in Malawi: Paper presented at the Joint 3rd African Association of Agricultural Economists (AAAE) and 48th Agricultural Economists Association of South Africa (AEASA) Conference, Cape Town, South Africa, September 19-23.

Simtowe F, Zeller M, 2006. The Impact of Access to Credit on the Adoption of hybrid maize in Malawi: An Empiric.al test of an Agricultural Household Model under credit market failure. MPRA Paper No. 45

Thuo MW, Bravo-Ureta BE, Obeng-Asiedu K, Hathie I, 2014. The adoption of agricultural inputs by smallholder farmers: The case of an improved groundnut seed and chemical fertilizer in the Senegalese groundnut basin. J Dev Areas, 48(1): 61-82.

Vabi MB, Sadiq AS, Mustapha A, Affognon H, Ajeigbe AH, Kasim AA, 2019. Patterns and drivers of the adoption of improved groundnut technologies in North-western Nigeria. Afr J Agric Sci, 6(1): 1-16.
Citation: Vabi MB, Ajeigbe HA, Kasim AA, Sadiq SA, Bala L, 2019. Adoption of varietal and accompanying groundnut technologies in Sokoto and Kebbi States of Northwestern Nigeria. Net J Agric Sci, 7(2): 56-68. 